\title{
REITs and the Financial Crisis: Empirical Evidence from the U.S.
}

\author{
Tobias Basse (Corresponding author) \\ Norddeutsche Landesbank (NORD/LB) and FHDW Hannover (University of Applied Sciences) \\ Norddeutsche Landesbank (NORD/LB), Friedrichswall 10, 30159 Hannover, Germany \\ Tel: 49-511-361-9473 E-mail: tobias.basse@nordlb.de
}

Meik Friedrich

Norddeutsche Landesbank (NORD/LB) and NORD/Advisors

Friedrichswall 10, 30159 Hannover, Germany

Eduardo Vazquez Bea

Norddeutsche Landesbank (NORD/LB)

Friedrichswall 10, 30159 Hannover, Germany

\begin{abstract}
REITs are often seen to be very similar to utility stocks. However, the current financial crisis - which has its roots in the U.S. housing market - has raised some doubts regarding this classification. We re-examine the relationship between REITs and utility stocks analyzing data from the United States and document the existence of a massive structural break in February 2007. Our results indicate that investing in U.S. REITs recently has become more risky relative to investments in utility stocks. This change coincides with the current economic and financial crisis.
\end{abstract}

Keywords: REITs, Financial crisis, Structural change

\section{Introduction}

By definition, real estate investment trusts (REITs) invest their funds primarily in real estate assets. While being a relatively new asset class in Europe, REITs already do have a long history in the U.S.. In fact, Congress already created the legislative framework for REITs in the 1960s. This legislative framework, for example, forces U.S. REITs to designate at least $90 \%$ of their taxable income to shareholders via dividend payments.

It appears to be quite challenging to adequately classify REITs either as stock market or real estate investments. As a matter of fact, many econometricians have analysed the relationship between REITs, the aggregate stock market and "more traditional" real estate assets. Mueller and Pauley (1995), for example, have argued that REITs are often seen to be very similar to utility stocks which are traditionally assumed to be one of the most defensive sectors of the equity market due to their non-cyclical business activities. The rationale behind this classification is understandable given the usually high dividend payments and the strong relative performance of U.S. REITs in the aftermath of the bursting of the dot-com bubble in 2001.

However, some doubts on the point of view that REITs and utility stocks are similar may be reasonable because of the current financial crises - which obviously has its roots in the U.S. housing market. Therefore, this paper aims to re-examine the relationship between REITs and utility stocks analyzing data from the United States. More specifically, the objective of this study is to examine whether the relationship between U.S. utility stocks and REITs, which have commonly been regarded to be close substitutes, has changed due to the financial crisis. In section 2 we review the literature on linkages between REITs, house prices, and the stock market. Section 3 discusses origins and consequences of the global financial crisis. Section 4 provides information about the data sets analyzed. In section 5 we address methodological issues and then present the results of our empirical investigations before concluding in section 6 .

\section{Literature review}

For the U.S. there is mixed empirical evidence as to whether REITs have or have not a systematic link to either the aggregate stock market or the real estate market. Accordingly, there remains severe uncertainty among professional asset managers in the assessment of this asset class as, for example, has been confirmed by a survey conducted by 
Worzala and Bajtelsmit (1997). However, the question whether REITs are stocks or real estate investments has been discussed and analyzed quite extensively. As early as 1987 Kuhle (1987) has reported empirical evidence indicating that, to a certain extend, REITs could offer benefits of diversification for investors holding equities. Those well recognised findings triggered a number of follow up research papers. Mull and Soenen (1997), for example, questioned this diversification potential and found positive correlations between the yields of REITs and traditional stock investments. Similar empirical evidence has also been reported by Bharati and Gupta (1993), Mueller and Pauley (1995), Chandrashekaran (1999) and He, Webb and Myer (2003). Chandrashekaran (1999) has pointed towards significant instabilities in the correlations between the returns of the two asset classes. Similar results have also been presented by Ghosh, Miles and Sirmans (1996) as well as Liang and McIntosh (1998). Corgel, Mcintosh and Ott (1995) have published a very comprehensive overview on the topic in the mid-1990s. Therefore, this paper concentrates on more recent research.

Oppenheimer and Grissom (1998) delivered more evidence for a positive correlation between stocks and REITs using techniques of cross-spectral time series analysis. Moreover, Han and Liang (1995) have shown that the relationship between REITs and the US stock market is more pronounced for the CRSP Index than the S\&P 500. This finding could be explained by the small cap effect as REITs in general have a rather low market capitalization. Lee and Stevenson (2005) have confirmed the existence of a rather strong relationship between REITs and small caps. Stevenson (2002) has investigated the transmission of volatility between REITs and traditional stock investments employing a GARCH-model and has confirmed the existence of a tight link between REITs on the one hand and small caps as well as value stocks on the other.

There is also mixed evidence for cointegration between the two asset classes. Wilson and Okunev (1999) have not been able to show that cointegration exists, whereas Glascock, Lu and So (2000) have reported empirical evidence indicating that cointegration has become a relevant phenomenon in recent years.

Looking at the relationship between REITs and the real estate market the empirical evidence is also mixed. Pagliari and Webb (1995) have only found a weak statistical link. Giliberto (1990) as well as Stevenson (2001) have even stated that there is no positive correlation between the returns of the two asset classes at all. However, employing multifactor models, Giliberto (1990) has reported that both asset classes feature a common real estate specific factor. Cointegration between REITs and house prices was found by $\mathrm{He}(2000)$, which implies tight co-movements and the existence of a stable long-term equilibrium relationship between the respective time series. These findings have been confirmed by Glascock, Lu and So (2000) as well as by Nishigaki (2007).

Apparently, the question whether REITs are stocks or real estate investments is hard to answer. Myer and Webb (1993) have used a number of different econometric techniques (i.a. Granger causality tests) and - depending on the method used - have found evidence that supports both, the hypothesis that REITs are more closely linked to the stock as well as to the real estate market. Therefore, they have concluded that there is no clear picture. Clayton and MacKinnon (2001) have shown that REITs indeed are similar to both asset classes but that the relationship varies over time. Their study seems to indicate that up to 1992 REITs have been linked closer to the equity market (more precisely to small caps) whereas in the period after that, the relationship to the real estate market has become more predominant.

Given the question examined here one of the most important studies found in the literature has been published by Mueller and Pauley (1995). They have argued that only utilities have a stronger negative correlation to interest rate changes than REITs discussing the bond-like qualities of utility stocks. Ghosh, Miles and Sirmans (1996) have also noted that REITs are often compared to utility stocks. Their empirical findings, however, do not support this commonly held assumption.

\section{The global financial crisis}

The current financial crisis has culminated in one of the most severe economic downturns in modern history - probably even the worst since the Great Depression. The causes for the breakdown are manifold. Still, systematically underestimated risks can be seen as major cause for the almost collapse of the global financial system. The roots of the current financial crisis lie in the U.S. housing and mortgage market. A surplus of available funds from abroad generated by the macroeconomic imbalances in the U.S.-centric global economy combined with a sustained decrease of U.S. interest rates at the beginning of the new millennium induced a housing boom in the U.S. until spring 2007. This boom was heated by a rapid and careless expansion of mortgage lending with an unusually low compensation for risk-taking. Lending decisions were taken under the faulty assumption of ever rising real estate prices.

At the same time, after the burst of the dot-com bubble in 2001, investors around the world searched for investment alternatives that were both, presumed to be safe and profitable. This was also a consequence of declining returns on many traditional safe long-term investments (e.g., government bonds). The financial industry reacted to this new environment and designed capital market instruments which derived their value from mortgage payments and house prices (e.g., mortgage-backed securities (MBS) and collateralized debt obligations (CDO)). In other words, relatively 
illiquid financial assets were transformed into liquid and tradable capital market instruments. In doing so, market participants all around the world were enabled to participate in the booming U.S. housing market. Furthermore, by distributing (e.g. selling) the originated mortgages the financial institutions regained liquidity, which could then be used for additional mortgage activities. As a result, the amount of these financial innovations increased massively in the years leading up to the start of the crisis in 2007 - a boom in the mortgage market was unleashed.

However, such securitized products combined many individual loans in complex, to some extent even abstruse, ways. These new products became so complicated that market participants - even the firms that designed the securities - were not able to entirely comprehend the risks inherent to these financial innovations. Even authorities (e.g. policy-makers, regulators, supervisors) and rating agencies did not fully understand all aspects of these products.

The credit boom began to unravel in early 2007 when signs of economic weakness started to appear and a downward spiral was triggered that continues up to now (see, for example, Wheelock (2008)). The rise of interest rates pressurized mortgaging and suppressed real estate demand. House prices in parts of the U.S. began to fall, (sub prime) mortgage delinquencies and defaults rose, forced sales of collaterals increased and the downturn in house prices intensified. Global financial institutions that had borrowed and invested heavily in the financial innovations described above started to experience major problems due to significant losses.

The crisis deepened in September 2008 when the failure or near-failure of several major financial institutions caused market participants to panic (see, for example, Bullard (2009)). As a consequence, financial and credit markets froze up. The gloomy economic prospects and the loss of confidence in the financial sector had a huge negative impact on share prices all over the world. Falling stock markets, a swaying financial system, and an emerging credit crunch triggered an extremely rapid and deep contraction in global economy which persisted through the first months of 2009.

\section{Data}

Our empirical investigations are based on two time series: the Dow Jones Composite REIT Total Return Index and the S\&P 500 Utilities Total Return Index. The Dow Jones Composite REIT Total Return Index is a common measure for U.S. REITs containing all publicly traded REITs in the Dow Jones universe. The S\&P 500 Utilities Total Return Index includes the members of the S\&P 500 that are involved in the utility sector. Trying to avoid problems with heteroscedasticity we analyse data with monthly periodicity. Due to the dramatic growth of market capitalization of U.S. REITs since the mid-1990s we chose the sample interval January 1999 to June 2009.

\section{Methodology and results}

ADF- and PP-tests (not reported) seem to indicate quite clearly that the two time series are nonstationary and integrated of order 1. Therefore, we have tested for cointegration between REITs (REIT) and utility stock prices (UTIL) both on levels and logarithms of levels using the technique suggested by Johansen (1991). Applying the Johansen procedure we at first assume that a linear deterministic trend exists. The tests performed do not indicate that there exists a cointegration relationship between the two variables (see notes table 1 and 2). This result is quite robust to different trend assumptions (see notes table 3 and 4). Given that the variables examined are integrated of order 1 differencing once leads to stationary. Without the existence of a cointegration relationship differencing integrated time series does not result in the loss of valuable information. Thus, we have estimated a simple linear regression model in first differences of logarithms which can be interpreted as monthly returns. The regression equation is (t-statistics in parenthesis):

$$
\begin{gathered}
\Delta \ln (\text { REIT })=\begin{array}{ll}
0.003+ & 0.602 \\
(0.72) & (6.65)
\end{array} \cdot \Delta \ln (\mathrm{UTIL}) \\
\mathrm{R}^{2}: 0.265 \text {, AIC: }-3.104, \mathrm{DW}: 1.486
\end{gathered}
$$

Where $\Delta$ is the difference operator. This regression equation can be regarded as a special version of the market model with the return of the utilities sector index as benchmark and the return of the REIT index as dependent variable. As suspected the market model beta is a statistically significant positive variable. However, the $\mathrm{R}^{2}$ of the regression is quite low. This might be a surprise.

Given that some econometricians have documented a close link between U.S. REITs and house prices in the United States it might be reasonable to suspect that the financial crises has caused structural change affecting the relationship between REITs and utility stocks. Therefore, we use the Quandt-Andrews breakpoint test (Andrews (1993)) for structural change with unknown timing (see notes table 5) to test for the stability of the estimated parameters. Using this test requires to remove a number of observations from the beginning and the end of the estimation sample in order for EViews to report valid p-values. Symmetrically trimming $15 \%$ of the observations by excluding the first and last 7,5\% of the data points reduces the test sample to the period August 2000 to November 2007. Hence, there are 87 possible break points. Examining the results the test does suggest quite clearly that there exists a massive structural break. The 
most likely breakpoint date is February 2007. This result is interesting because the breakpoint identified by the Quandt-Andrews breakpoint test seems to coincide with the first obvious signs indicating an overheating of U.S. house prices.

Given the clear evidence for a massive structural break in February 2007 reported above we have re-estimated equation (1) for the two samples February 1999 to January 2007 (equation (2)) and February 2007 to June 2009 (equation (3)).

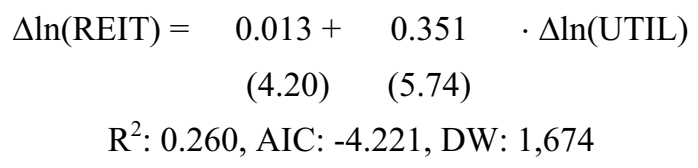

$$
\begin{gathered}
\Delta \ln (\text { REIT })=\begin{array}{cc}
-0.020 & 1.156 \\
(-1,33) & (4,29)
\end{array} \cdot \Delta \ln (\mathrm{UTIL}) \\
\mathrm{R}^{2}: 0.405, \text { AIC: }-2.159, \mathrm{DW}: 1.606
\end{gathered}
$$

There are just enough data points to estimate equation (3). The results of the two regressions signal an indubitable increase of the market model beta indicating that during the crisis the risk of REITs investments has increased considerably relative to the utility sector.

\section{Conclusion}

The empirical evidence found above quite clearly indicates that the relationship between the monthly return on the utilities sector equity index and the return on the REIT index has changed dramatically. Investing in REITs seems to have become more risky relative to investments in utility stocks. This change coincides with the current economic and financial crisis - which, of course, has its roots in the U.S. housing market. Therefore, this structural break is most probably directly related to the current crisis. Our findings do have a number of implications. Most importantly, we have shown that a major macroeconomic crisis can also have additional - and more microeconomic - effects on the relationship between financial assets that have been thought to be quite similar. More specifically, Reddemann et al. (2009) have argued that structural breaks in linear regressions of the type displayed in equation (1) can be a sign of instability and time variation of the correlations between the returns of the asset classes examined. Therefore, the empirical evidence reported above is also a reminder of the fact that the correlation matrices of returns on different financial assets regularly used in financial optimizations are not necessarily stable over time. In fact, financial markets are always on the move.

\section{References}

Andrews, D. W. K. (1993). Tests for parameter instability and structural change with unknown change point. Econometrica, 61, 821-856.

Bharati, R. \& Gupta, M. (1993). Asset allocation and predictability of real estate returns. Journal of Real Estate Research, 7, 469-484.

Bullard, J. (2009). Three funerals and a wedding. Federal Reserve Bank of St. Louis Review, 91, 1-12.

Chandrashekaran, V. (1999). Time-series properties and diversification benefits of REIT returns. Journal of Real Estate Research, 17, 91-112.

Clayton, J. \& MacKinnon, G. (2001). The time-varying nature of the link between REIT, real estate and financial asset returns. Journal of Real Estate Portfolio Management, 7, 43-54.

Corgel, J. B., Mcintosh, W. \& Ott, S. H. (1995). Real estate investment trusts: A review of the financial economics literature. Journal of Real Estate Literature, 3, 13-33.

Giliberto, S. M. (1990). Equity real estate investment trusts and real estate returns. Journal of Real Estate Research, 5 , 259-264.

Glascock, J. L., Lu, C. \& So, R. W. (2000). Further evidence on the integration of REIT, bond, and stock returns. Journal of Real Estate Finance and Economics, 20, 177-194.

Ghosh, C., Miles, M. \& Sirmans, C. F. (1996). Are REITs stocks?, Real Estate Finance, 13, (1996), 46-53.

Han, J. \& Liang, Y. (1995). The historical performance of real estate investment trusts. Journal of Real Estate Research, $10,235-262$.

He, L. T. (2000). Causal relationships between apartment REIT stock returns and unsecuritized residential real estate. Journal of Real Estate Portfolio Management, 6, 365-372. 
He, L. T., Webb, J. R. \& Myer, F. C. N. (2003). Interest rate sensitivities of REIT returns. International Real Estate Review, 6, 1-21.

Johansen, S. (1991). Estimation and hypothesis testing of cointegration vectors in gaussian vector autoregressive models. Econometrica, 59, 1551-1580.

Kuhle, J. (1987). Portfolio diversification and returns benefits - common stock vs. real estate investment trusts. Journal of Real Estate Research, 2, 1-9.

Lee, S. \& Stevenson, S. (2005). The case for REITs in the mixed-asset portfolio in the short and long run. Journal of Real Estate Portfolio Management, 11, 55-80.

Liang, Y. \& McIntosh, W. (1998). REIT style and performance. Journal of Real Estate Portfolio Management, 4, 69-78.

Mueller, G. R. \& Pauley, K. R. (1995). The effect of interest-rate movements on real estate investment trusts. Journal of Real Estate Research, 10, 319-326.

Mull, S. R. \& Soenen, L. A. (1997). U.S. REITs as an asset class in international investment portfolios. Financial Analysts Journal, 53, 55-61.

Myer, F. C. N. \& Webb, J. R. (1993). Return properties of equity REITs, common stocks, and commercial real estate: A comparison. Journal of Real Estate Research, 8, 87-106.

Nishigaki, H. (2007). An analysis of the relationship between US REIT returns. Economcis Bulletin, 13, 1 - 7.

Reddemann, S., Basse, T., Friedrich, M. \& Schulenburg, \& J.-M. v. d. (2009). Hedge-Fonds als Asset-Klasse: Betrachtungen aus der Perspektive der deutschen Versicherungswirtschaft, Zeitschrift für die gesamte Versicherungswissenschaft, 98, 273-281.

Oppenheimer, P. \& Grissom, T. V. (1998). Frequency space correlation between REITs and capital market indices. Journal of Real Estate Research, 16, 291-310.

Pagliari, J. L. \& Webb, J. R. (1995). A fundamental examination of securitized and unsecuritized real estate. Journal of Real Estate Research, 10, 381-426.

Stevenson, S. (2001). The long-term advantages to incorporating indirect securities in direct real estate portfolios. Journal of Real Estate Portfolio Management, 7, 5-16.

Stevenson, S. (2002). An examination of volatility spillovers in REIT returns. Journal of Real Estate Portfolio Management, 7, 229-238.

Wheelock, D. C. (2008). The federal response to home mortgage distress: Lessons from the great depression. Federal Reserve Bank of St. Louis Review, 89, 133-148.

Wilson, P. J. \& Okunev, J. (1999). Long-term dependencies and long run non-periodic co-cycles: Real estate and stock markets. Journal of Real Estate Research, 18, 257-278.

Worzala, E. M. \& Bajtelsmit V. L. (1997). Real estate asset allocation and the decisionmaking framework used by pension fund managers. Journal of Real Estate Portfolio Management, 3, 47-56. 


\section{Notes}

Table 1. Cointegration between REITs and utilities

Lags interval (in first differences): 1 to 4

Unrestricted Cointegration Rank Test (Trace)

\begin{tabular}{ccccc}
\hline \hline $\begin{array}{c}\text { Hypothesized } \\
\text { No. of CE(s) }\end{array}$ & Eigenvalue & $\begin{array}{c}\text { Trace } \\
\text { Statistic }\end{array}$ & $\begin{array}{c}0.05 \\
\text { Critical Value }\end{array}$ & Prob. $^{* *}$ \\
\hline \hline None & 0.070031 & 12.71190 & 25.87211 & 0.7604 \\
At most 1 & 0.031933 & 3.926870 & 12.51798 & 0.7527 \\
\hline \hline
\end{tabular}

Trace test indicates no cointegration at the 0.05 level

* denotes rejection of the hypothesis at the 0.05 level

**Critical values from EViews

Unrestricted Cointegration Rank Test (Maximum Eigenvalue)

\begin{tabular}{ccccc}
\hline \hline $\begin{array}{c}\text { Hypothesized } \\
\text { No. of CE(s) }\end{array}$ & Eigenvalue & $\begin{array}{c}\text { Max-Eigen } \\
\text { Statistic }\end{array}$ & $\begin{array}{c}0.05 \\
\text { Critical Value }\end{array}$ & Prob.** \\
\hline \hline None & 0.070031 & 8.785033 & 19.38704 & 0.7463 \\
At most 1 & 0.031933 & 3.926870 & 12.51798 & 0.7527 \\
\hline \hline
\end{tabular}

Max-eigenvalue test indicates no cointegration at the 0.05 level

* denotes rejection of the hypothesis at the 0.05 level

** Critical values from EViews 
Table 2. Cointegration between REITs and utilities (in logarithms)

Lags interval (in first differences): 1 to 4

Unrestricted Cointegration Rank Test (Trace)

\begin{tabular}{ccccc}
\hline \hline $\begin{array}{c}\text { Hypothesized } \\
\text { No. of CE(s) }\end{array}$ & Eigenvalue & $\begin{array}{c}\text { Trace } \\
\text { Statistic }\end{array}$ & $\begin{array}{c}0.05 \\
\text { Critical Value }\end{array}$ & Prob.** \\
\hline \hline None & 0.039828 & 7.413438 & 15.49471 & 0.5301 \\
At most 1 & 0.020414 & 2.495695 & 3.841466 & 0.1142 \\
\hline \hline
\end{tabular}

Trace test indicates no cointegration at the 0.05 level

* denotes rejection of the hypothesis at the 0.05 level

** Critical values from EViews

Unrestricted Cointegration Rank Test (Maximum Eigenvalue)

\begin{tabular}{ccccc}
\hline \hline $\begin{array}{c}\text { Hypothesized } \\
\text { No. of CE(s) }\end{array}$ & Eigenvalue & $\begin{array}{c}\text { Max-Eigen } \\
\text { Statistic }\end{array}$ & $\begin{array}{c}0.05 \\
\text { Critical Value }\end{array}$ & Prob. ** $^{*}$ \\
\hline \hline None & 0.039828 & 4.917743 & 14.26460 & 0.7522 \\
At most 1 & 0.020414 & 2.495695 & 3.841466 & 0.1142 \\
\hline \hline
\end{tabular}

Max-eigenvalue test indicates no cointegration at the 0.05 level

* denotes rejection of the hypothesis at the 0.05 level

** Critical values from EViews 
Table 3. Cointegration between REITs and utilities with different trend assumptions

\begin{tabular}{ccccc}
$\begin{array}{c}\text { Number of } \\
\text { Cointegrating } \\
\text { Relations }\end{array}$ & & & & \\
\hline \hline Data Trend: & None & None & Linear & Linear \\
\hline Test Type & No Intercept & Intercept & Intercept & Intercept \\
& No Trend & No Trend & No Trend & Trend \\
Trace & 0 & 0 & 0 & 0 \\
Max-Eig & 0 & 0 & 0 & 0 \\
\hline \hline
\end{tabular}

Critical values (0.05 level) from EViews

Table 4. Cointegration between REITs and utilities with different trend assumptions (in logarithms)

Number of

Cointegrating

Relations

\begin{tabular}{ccccc}
\hline \hline Data Trend: & None & None & Linear & Linear \\
\hline Test Type & No Intercept & Intercept & Intercept & Intercept \\
& No Trend & No Trend & No Trend & Trend \\
Trace & 0 & 0 & 0 & 0 \\
Max-Eig & 0 & 0 & 0 & 0 \\
\hline \hline
\end{tabular}

Critical values (0.05 level) from EViews

Table 5. Quandt-Andrews breakpoint test

Quandt-Andrews unknown breakpoint test

Null Hypothesis: No breakpoints within trimmed data

Varying regressors: All equation variables

Equation Sample: 1999M02 2009M06

Test Sample: 2000M09 2007M11

Number of breaks compared: 87

\begin{tabular}{llc}
\hline \hline Statistic & Value & Prob. \\
\hline \hline Maximum LR F-statistic (2007M02) & 16.46953 & 0.0059 \\
Maximum Wald F-statistic (2007M02) & 16.46953 & 0.0059 \\
& & \\
Exp LR F-statistic & 6.791876 & 0.0016 \\
Exp Wald F-statistic & 6.791876 & 0.0016 \\
& & 0.0012 \\
Ave LR F-statistic & 10.32026 & 0.0012 \\
Ave Wald F-statistic & 10.32026 & \\
\hline \hline
\end{tabular}

